\title{
Гетерозис у 56-хромосомных апомиктичных кукурузно-трипсакумных гибридов
}

\author{
Панихин П.А. ${ }^{1,2 *}$, Соколов В.А. ${ }^{1}$ \\ ${ }^{1}$ Институт молекулярной и клеточной биологии СО РАН, Новосибирск, Россия \\ ${ }^{2}$ Всероссийский институт генетических ресурсов растений имени Н.И. Вавилова, \\ Санкт-Петербург, Россия \\ *e-mail:panikhin@mcb.nsc.ru
}

Апомиксис обладает потенциальной возможностью революционизировать растениеводство и значительно повысить рентабельность и урожайность в этой весьма затратной отрасли сельского хозяйства. Все действующие в настоящее время селекционные технологии по использованию гетерозиса основаны на работе с сексуально размножающимися растениями. В этой связи они несут свойственный им недостаток - сегрегацию по хозяйственно ценным признакам в ряду поколений после $\mathrm{F}_{1}$, что требует проведения ежегодного и очень затратного воспроизводства гибридов. Эта проблема может быть решена с привлечением бесполосеменного размножения. Один из путей практического использования апомиксиса для закрепления гетерозиса связан с заимствованием его у диких сородичей культурных растений. В этой связи необходимо оценить, как сильно генетический материал дикого родителя будет влиять на экспрессию гибридной мощности. Исследования, проведенные на растениях разных родов, показывают, что межвидовые гибриды, как правило, проявляют более высокий гетерозис, чем внутривидовые гибриды, если генетическая разница между видами или родами не мешает им формировать совместимые скрещивания. С целью закрепления гетерозиса у кукурузы и получения перспективного селекционного материала был предложен путь гибридизации между Zea mays и Tripsacum dactyloides $(2 n=4 x=72)$ - донора признака апомиктического способа репродукции. Создание 56-хромосомных кукурузно-трипсакумных гибридов $(2 n=56=20 \mathrm{Zm}+36 \mathrm{Td})$ строилось по схеме последовательной гибридизации линий кукурузы (линия 573 и линия 611), используемых для получения коммерческих гибридов $\mathrm{F}_{1}$, с гамаграссом. Из полученных форм 56-хромосомных гибридов три формы с родительскими $2 n=56=(20 \mathrm{Zm}$ (линия 573$)+36 \mathrm{Td}) ; 2 n=56=(20 \mathrm{Zm}$ (линия 611$)+$ $36 \mathrm{Td})$ и гетерозисной $(2 n=56=[(10 \mathrm{Zm}$ (линия 573) $+36 \mathrm{Td})+10 \mathrm{Zm}$ (линия 611) $]$ комбинациями кукурузных геномов экспрессируют признак апомиктического воспроизводства. Исследование данных форм показало, что 56-хромосомные апомиктичные гибриды, у которых присутствуют геномы линий 573 и 611, превосходят контроли, где оба генома только от одной из этих линий: по массе зерновки, скорости роста, биохимическим показателям и урожайности зеленой массы, что говорит о том, что у данной формы гибрида экспрессируется гетерозис. 